\title{
Development of Midwifery Learning Model with Spiritual Approach in the Midwifery Concept Course
}

\author{
Hasnerita $^{1}$, Suyitno Muslim², Atwi Suparman ${ }^{3}$ \\ \{anerita_tp13s3@mahasiswa.unj.ac.id ${ }^{1}$, suyitno@unj.ac.id ${ }^{2}$, atwisuparman@gmail.com ${ }^{3}$ \} \\ Universitas Negeri Jakarta, Indonesia ${ }^{12}$ \\ Universitas Terbuka, Indonesia ${ }^{3}$
}

\begin{abstract}
This study resulted in acquiring knowledge about learning models of spiritual midwifery services with ideal methods of assessment and labor. The research methodology implemented includes research and development. There were 10 steps used as a basis for developing a model in research and development by Borg and Gall. Before using the instrument, validation is carried out by competent experts. The product testing phase begins with the validation of several material, design and media experts. Furthermore, the product will support one to one learners for the overall average score of 4.33 or $86.6 \%$, the small group trials get an average value of 4.37 or $87.5 \%$, while the large group trials get an average score of 4.48 , or $89.65 \%$. The results of the learning process indicate an average level of 3.84 which correlates with what has been agreed.
\end{abstract}

Keywords: Development Research, Spiritual approach, Midwifery learning models.

\section{Introduction}

Midwives as health workers have the duty and competence to assist with normal childbirth. As one of the most strategic health workers, they have an important role in preparing quality future generations by providing continuous and complete services for pregnant women, newborns, toddlers as well as reproductive health women. Their services focus on prevention aspects through health education, counseling and health promotion based on partnerships and women's empowerment, as well as conducting early detection, first aid in emergency and safe referrals [1]. In modern obstetric services, women are considered subjects for the care of institutional routines, which may have adverse effects on the progress of labor. Supportive care during childbirth in the form of emotional support, comfort, information and advocacy measures, can improve women's physiological work processes, and can control their feelings and competencies, thereby reducing the need for obstetric interventions. Mary Gabay and Sidney Wolve's MD Cesarean Sections: Curing a National Epidemic, are not needed writes: "It is not realized that every day cesarean section is not necessary for thousands of women, wasting millions of dollars worth of valuable health care while nearly 40 million people in America lack Health Insurance "[2]. According to data from the World Health Organization (WHO), childbirth with cesarean section is around $10-15 \%$ of all deliveries in developing countries. Pregnancy and/or pathological labor only occurs in about $10-12 \%$ of all cases of pregnancy and 
childbirth. In other words, most or around $88-90 \%$ of pregnancies or deliveries take place normally or without complications. However, this situation can change with the assistance of an individual midwife or the midwifery profession, without those consumers who increasingly oppose midwifery regulations in obstetric units. The International Confederation of Midwives has emphasized that normal childbirth is threatened with extinction, meanwhile, in the UK the Royal College of Midwives has placed normal childbirth as the top agenda through the campaign of "Fighting for Normal" [3].

The rate of surgeries for cesarean section in Indonesia has exceeded the maximum WHO standard of 5-15\%. From the National Survey in 2009, there were 921,000 cesarean deliveries out of a total of $4,039,000$ deliveries. This means that about $22.8 \%$ of all deliveries were cesarean and according to RIKESDAS data in 2010, the rate of cesarean section delivery in Indonesia was $15.3 \%$ of 20,591 mothers interviewed in 33 provinces who gave birth within the last 5 years[4]. The Royal College of Obstetrics and Gynecologists 2007 issued guidelines for implementing vaginal delivery after section surgeries (VBAC) recommended facilitating practice by providing counseling and support for joint decision making. Additionally, support, professional midwives and doctors can help women to try VBAC because they need effective communication and information support [5].

Efforts that have been made by the Royal College of Midwives 2004 have placed normal birth at the top of the agenda of 'fighting for normality' through the 'Normal Birth Campaign'. Expert professional midwives who are skilled in supporting and maximizing normal birth must have their skills promoted and valued. The role of midwives is an integral part of the care model, which promotes normality. Maternity services can improve midwifery and autonomous skills by providing appropriate practice settings[3].

\section{Research Methodology}

The general objective of learning is through midwifery services with a spiritual approach in assisting mothers with pregnancy, childbirth, babies, and postpartum so that babies are born physiologically. Pregnancy and childbirth are chains that cannot be separated in the lives of normal women. Because the human body has been prepared for normal childbirth, both physically and mentally, only motivation and awareness is required to return to the concept of natural labor.

This research was conducted at the Polytechnic III Ministry of Health in the Jakarta Midwifery Study Program, Jalan. Jasmine 2 N0. 15 Jatiwarna Pondok Melati, Bekasi 17415 West Java; this place was chosen because of the commitment from the Ka. Midwifery Study Program and instructors who conduct a curriculum development in improving midwifery education quality. Students are able to assist in childbirth and are very helpful in this study.

\section{Research Results And Discussion}

The Researchers first conducted preliminary research. This research in the form of needs analysis is a model for the pursuit of a spiritual midwifery approach, one of the goals for improving the Midwifery D IV curriculum. An overview of the understanding of the DIV Midwifery curriculum that was applied at this time, which was carried out through interviews, was obtained. 
The development model starts from the conceptual design model for the development of spiritual midwifery learning designs, with: Learning the spiritual dimension of education enables students to engage in activities in order to know themselves and their true nature, not only with their thoughts but also through feelings and imagination, to realize and develop their own potential, and to actualize themselves in their particular educational environment. Similarly, it supports the importance of multiple intelligences (Gardner), and emotional intelligence (Goleman) in education.

After validation by the team, the next process is to conduct field trials. These trials were conducted to see the effectiveness of the model to be developed which will be seen from the usefulness of the model being developed and from several responses and assessments from users/students.

The process of testing is done in three stages, consisting of 1. Trial individual (one to one learner), 2. Trial group (small group), 3. Trial major groups (field trial). These three stages are carried out to see the effectiveness of the model being developed.

Student responses assess the feasibility of the model and attitudes of students towards this Model yield an average value of 4.25 or $85 \%$. The material given is very relevant in the revolutionary holistic midwifery care and physiology because midwives must also know that there are many benefits of brain function, hormones, a conscious mind and subconsciousness, especially for midwifery students. The material is not only useful and knowledgeable for midwives and for the community, but women can also read and apply it during pregnancy and childbirth. The material is not too difficult and can be reached by anyone especially with case studies / some birth experiences.

Results obtained from small groups (Small Group) include five indicators of model effectiveness developed, namely; 1) attractiveness of learning material, 2) duration/time of learning, 3) level of material difficulty, 4) suitability of use of illustrations, 5) suitability of tests with learning objective. The response of students to the trial of indicators can be described as follows.

Overall, from the quality of the responses of small group trial students towards the acceptance and usability of the developed model, it can be concluded that the Midwifery spiritual approach learning model for Midwifery D IV students is feasible and can be continued in the group trials field. Results obtained from large groups (Field Trials), include three indicators of effectiveness. The model developed consists of; 1) attractiveness of learning material, 2) suitability of material with science and technology, 3) product feasibility and 4) assessment of the learning process through observation. It can be concluded that the design product of the spiritual midwifery learning system that has been developed is feasible and can be used (recording comments of several students). Test description: This field try reflects the characteristics of the end user of the product being developed.

The overall results indicate that the value quality achieved is likely to pay attention to the level of effectiveness of the product being developed. In addition, product effectiveness can be seen from the average starting from individual trials at the level of $86.11 \%$, small group trials at the level of $87 \%$ and field trials at the level of $89.14 \%$ with an overall average of $87.42 \%$ in the very good category. Responses: The overall pilot students are illustrated in the following graph (Final Draft Model). 


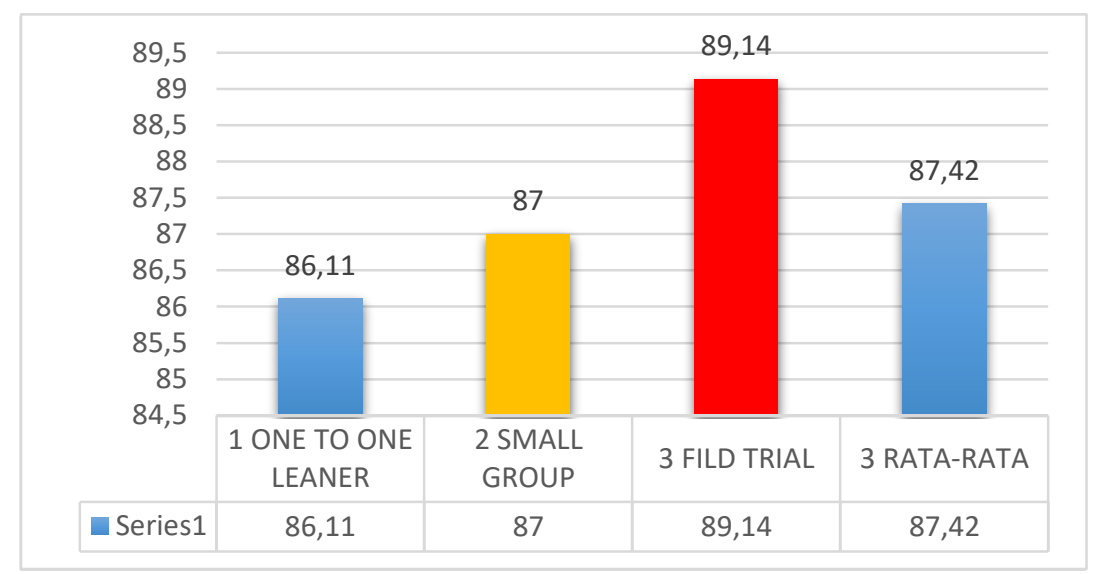

Fig 1. Graph of Results of Student Acceptance Levels in the Spiritual Midwifery Learning Model

The effectiveness level of individual trial models, small group trials, and field trial results can also be seen from the quality of the formative assessment results of the initial tests and the final tests showing that this model is effective. The trial results in the field numbered 29 include people whose results from the average pretest were 45.62 and the average result of the test post was 70.76. The average number was still at a good value with the presentation of the increase in value at 25.14. The results of the pretest and test post are illustrated as follows;

\section{Discussion}

This section will present the discussion of the results of the expert team's assessment and the results of field trials. Discussion of data on development results will be presented in five parts, namely 1) attractiveness of learning material, 2) suitability of material with science and technology, 3) product feasibility, 4) weaknesses and 5) product excellence.

1. Attractive Learning Material

The results of the responses from the large group trials about the attractiveness of spiritual midwifery learning materials are quite interesting, illustrated by the average level of 4.48, or $89.65 \%$. According to the students; very interesting and systematic, not emotional, lots of new things, gives examples, facilitates understanding, and the glossary is very helpful. This learning material is suitable to be used as a learning resource because it can improve the competence of midwives. Supported by expert opinion, the truth of the concepts explained is in accordance with the scope of midwife disciplines and can be accounted for by the relevant science because it already uses relevant sources. Based on the results of the validation of conformity, the competency in the model is very feasible with the average criteria of 5 or $100 \%$ meaning that the feasibility according to the material expert can be used as learning material in the midwifery concept.

In accordance with social cognitive theory, Dale H Schunk [6] says that in essence, human learning and the processes of interaction, behavior and examples model the experiences in their environment. Information obtained based on the results of observations, hearing the experiences 
of others, and the experience of doing so alone raises the confidence of new views of individuals. This can form knowledge, skills, and performance improvements as planned learning outcomes.

2. Suitability of the material with science and technology

The response from the trial is that students state new learning about spiritual obstetrics, the material is sequential and in accordance with evidence-based midwifery. The language is very interesting and complete with related research, drawn from the level of the average that reached $4: 58$ or $91.72 \%$, which is highly relevant to the competence of midwives.

In accordance with Expert opinions, spiritual obstetrics matter and have been following the development in disciplines that are cutting-edge for these obstetrics. Here, the world of obstetrics is up to date, not High technology but High Touch, so it will be a deeper spiritual touch where participants have begun to understand the values held by clients and families and have also begun to appreciate the power that affects labor in the psycho-spiritual.

Supported by PS Mueller research [7] and Retained Earnings experience, both might involve the search for meaning and purpose, transcendence, interconnectedness, and values. In this case, the involvement of religion is similar to spirituality. In accordance with Brian J's knowledge of religious and spiritual beliefs, experiences and behaviors have accumulated. With the new millennium approach, popular and scientific interests in religion and spirituality continue to grow.

\section{Product Feasibility}

Indicators of the feasibility of the products developed received a good response at an average level of 4.3 or $86.01 \%$. According to the trial students ranging from the model display; learning objectives, media and learning methods, descriptions of learning materials, summaries, exercises, and formative tests were worth it. The use of photos in the form of illustrations, video, and story success already has a good composition so as to provide attraction and motivation to read it. The content provided is very relevant in the revolutionary holistic midwifery care and physiology is easy to implement because there are concrete examples

supported by expert opinions. This spiritual obstetric material needed by users and students is considered very good by experts, achieving the average criteria of 5 or $100 \%$. This means that the material is needed because there is still a lack of learning material that can be applied and this model can increase midwives' confidence in maintaining natural childbirth.

Furthermore, the use of film media is carried out in order to strengthen the cognitive learning process, and optimize the power of audio and visuals as the strength of the participants. Also, creating pleasant conditions to optimize the power of the subconscious mind that is able to effect the function of the right brain in understanding and interpreting the material being studied. To keep the situation pleasant and comfortable so that the concentration and motivation of learning is maintained, music will accompany the stages of the learning process.

\section{Weaknesses of Research}

The weaknesses of the spiritual midwifery learning design are; first, the planning, evaluation and revision process is too focused on the midwifery substance, while the learning content lines, the learning implementation plan, the evaluation system and process, and the revision only arrive at the expert's review. Second, the scope of the trial is not maximized for Midwifery DIV Polytechnic III Jakarta Students. To socialize this program more broadly, it is necessary to collaborate with the Indonesian Midwives Association organization. Third, the trial 
process of spiritual midwifery learning requires a long time and high costs. Students are asked to keep practicing in the field in order to reflect the knowledge gained in practice. Fourth, students in the field trial did not have time to read learning materials and do the exercises, and so they could not practice spiritual midwifery in the field.

\section{Product Advantages}

The advantages of spiritual learning products are; first, this spiritual midwifery learning design has a structured and complete learning system. Second, the feasibility of spiritual midwifery learning has been proven and validated by experts who are competent in their fields. Third, the design of the conceptual model of learning starts from Spirituality, thought patterns, intra and interpersonal communication, to giving birth training, complementary therapy and how to maintain natural labor. Fourth, the theories underlying the development of learning models are Bandura theory and social, cognitive, constructivism, reflection, brain-based and spirituality learning. Fifth, the spiritual midwifery learning strategy varies with the sequential learning sequence, from the exercises and giving concrete examples, to films so that students can learn and firsthand experience. Sixth, this material can be studied independently by students according to their respective abilities.

\section{Conclusion}

From the entire research process of developing a spiritual midwifery learning system design model for midwifery DIV students, the following conclusions can be drawn;

1. The spiritual midwifery learning model developed has proven to be very useful, easily understood, and very interesting to study because it includes exercises, examples, films given based on facts and success stories are easy to apply.

2. The concept of midwifery is still based on theories, there are no guidelines or examples on how to apply it to various methods, media and evaluation systems. Answers from questionnaires and observations found the fact that the ability of lecturers to design a good and effective learning system is not optimal.

3. The process of developing a spiritual midwifery learning model is carried out in several stages; 1) identification of needs, including preliminary research, determination of learning objectives, identification of student characters and analysis of learning. 2) Designing and developing models include formulating specific objectives, and developing instruments, learning strategies, teaching materials and evaluation tools. 3) evaluation and revision include expert evaluation, evaluation of one student, small group trials, field trials and revisions.

\section{Reference}

[1] DepKes, R.: Standard Pelayanan Kebidanan', in Editor (Ed.)^(Eds.): 'Book Standard Pelayanan Kebidanan, pp (2013)

[2] Gibbons, L., Belizán, J.M., Lauer, J.A., Betrán, A.P., Merialdi, M., and Althabe, F.: The global numbers and costs of additionally needed and unnecessary caesarean sections performed per year: overuse as a barrier to universal coverage, World health report, 30, pp. $1-31(2010)$ 
[3] Midwives, R.C.o.: 'Campaign for normal birth' is launched', in Editor (Ed.)^(Eds.): 'Book Campaign for normal birth' is launched' (January 2005, edn.), pp. (2005)

[4] Sammlung, V., Kundra, R., and Karundeng, M.: 'Faktor-Faktor Yang Berperan Meningkatnya Angka Kejadian Sectio Caesarea Di Rumah Sakit Umum Daerah Liun Kendage Tahuna', Jurnal Keperawatan, 2, (1) (2014)

[5] Foureur, M., Turkmani, S., Clack, D.C., Davis, D.L., Mollart, L., Leiser, B., and Homer, C.S.: 'Caring for women wanting a vaginal birth after previous caesarean section: A qualitative study of the experiences of midwives and obstetricians', Women and Birth, 2017, 30, (1), pp. 3-8 (2017)

[6] Schunk, D.H.: 'Learning theories an educational perspective sixth edition' (Pearson, (2012)

[7] Mueller, P.S., Plevak, D.J., and Rummans, T.A.: 'Religious involvement, spirituality, and medicine: implications for clinical practice', in Editor (Ed.)^(Eds.): ‘Book Religious involvement, spirituality, and medicine: implications for clinical practice' (Elsevier, 2001, edn.), pp. 1225-1235 (2001)) 